\title{
EFFECTS OF EXPLANT TYPE, CULTURE MEDIA AND PICLORAM AND DICAMBA GROWTH REGULATORS ON INDUCTION AND PROLIFERATION OF SOMATIC EMBRYOS IN EUCALYPTUS GRANDIS X E. UROPHYLLA
}

\author{
Luciana Coelho de Moura $^{2 *}$, Aloisio Xavier ${ }^{3}$, Ana Claudia Ferreira da Cruz ${ }^{4}$, Ricardo Gallo ${ }^{5}$, Kellen \\ Cristina Gatti ${ }^{5}$, Natane Amaral Miranda ${ }^{5}$ and Wagner Campos Otoni ${ }^{6}$
}

\footnotetext{
${ }^{1}$ Received on 05.02.2017 accepted for publication on 07.06.2017.

${ }^{2}$ Universidade Federal de Viçosa, Doutorado em Ciência Florestal, Viçosa, MG - Brasil. E-mail: <lucianacm2005@yahoo.com.br>.

${ }^{3}$ Universidade Federal de Viçosa, Departamento de Engenharia Florestal, Viçosa, MG - Brasil. E-mail: <xavier@ufv.br>.

${ }^{4}$ Universidade Federal de Viçosa, Doutorado em Botânica, Viçosa, MG - Brasil. E-mail: <aclaudia5@hotmail.com>.

${ }^{5}$ Universidade Federal de Viçosa, Programa de Pós-Graduação em Ciência Florestal, Viçosa, MG - Brasil. E-mail: <gallo.florestal@gmail.com>,<kellencristinagatti@gmail.com>and <nataneamaral@gmail.com>.

${ }^{6}$ Universidade Federal de Viçosa, Departamento de Biologia Vegetal, Viçosa, MG - Brasil. E-mail: <wcotoni@gmail.com>. *Corresponding author.
}

\begin{abstract}
The objective of the present study was to test the effects of explant type, auxin concentrations, culture media, and auxin concentrations on the induction and proliferation of somatic embryos of Eucalyptus grandis $\mathrm{x}$ E. urophylla. Seeds and cotyledons were used as explants and inoculated in culture media containing $1.13,2.26,3.39$ and $4.52 \mu \mathrm{M}$ dicamba or $4.14,10.35,20.71$ and $31.06 \mu \mathrm{M}$ picloram. Embryogenic calli induced in the picloram treatments were used as explants and inoculated in semisolid or liquid media containing $4.14,10.35,20.71$ and $31.06 \mu \mathrm{M}$ picloram and keeping the origin of the embryogenic callus (seeds or cotyledons) and the concentration of picloram in those who were in the induction phase. Statistical, descriptive and anatomical analyses were performed. Induction of somatic pro-embryos into the juvenile plant material of Eucalyptus grandis $\mathrm{x}$ E. urophylla was performed using seeds or cotyledons as the source of explants, with the addition of dicamba and picloram as growth regulators. The use of cotyledons as a source of explants and the concentration of $4.1 \mu \mathrm{M}$ picloram added to the culture media resulted in a higher induction of somatic pro-embryos. Proliferation of secondary somatic embryos was achieved using liquid medium added with picloram.
\end{abstract}

Keywords: In vitro propagation; Micropropagation; Somatic embryogenesis.

\section{EFEITO DO TIPO DE EXPLANTE, DO MEIO DE CULTURA E DOS REGULADORES DE CRESCIMENTO DICAMBA E PICLORAM NA INDUÇÃO E PROLIFERAÇÃO DE EMBRIÕES SOMÁTICOS EM Eucalyptus grandis $X$ E. urophylla}

RESUMO - O objetivo do presente estudo foi testar o efeito do tipo de explante e concentrações de auxinas
na indução, bem como o efeito do meio de cultura e de concentrações de auxina na proliferação de embriões
somáticos de Eucalyptus grandis $x$ E. urophylla. Sementes e cotilédones foram utilizados como explantes
e inoculados em meio de cultura de induçáo contendo 1,$13 ; 2,26 ; 3,39$ e $4,52 \mu M$ de dicamba ou 4,$14 ;$
10,$35 ; 20,71$ e $31,06 \mu M$ de picloram. Calos embriogênicos induzidos nos tratamentos com picloram foram
utilizados como explantes e inoculados em meio semissólido ou líquido contendo 4,$14 ; 10,35 ; 20,71$ e 31,06
$\mu M$ de picloram, mantendo-se a origem dos calos embriogênicos (sementes ou cotilédones) e a concentração
de picloram em que os mesmos estavam na fase de indução. Foram realizadas análises estatísticas, descritivas 
e anatômicas. A indução de pró-embriões somáticos em material vegetal juvenil de Eucalyptus grandis $x$ E. urophylla pode ser realizada utilizando-se sementes ou cotilédones como fonte de explantes, e dicamba e picloram como reguladores de crescimento adicionados a meio de cultura. O uso de cotilédones como fonte de explantes e a concentração de 4,1 $\mu \mathrm{M}$ de picloram adicionado ao meio de cultura resultou em maiores médias na indução de pró-embriões somáticos, A proliferação de pró-embriões somáticos secundários pode ser obtida utilizando meio liquido adicionado de picloram.

Palavras-Chave: Propagação in vitro; Micropropagação; Embriogênese somática.

\section{INTRODUCTION}

In vitro plant regeneration systems have been widely used in breeding and biotechnology methods, such as micropropagation, haploid production, disease-free plant production, rejuvenation and genetic transformation (Rai and Shekhawat, 2014; Us-Camas et al. 2014). Somatic embryogenesis is a method used in the production of new embryos from pre-existing somatic embryos. Embryogenic callus systems are highly regenerable and can generate large numbers of propagules and hold for long periods.

Over the years, researchers have shown interest in using somatic embryogenesis for several species of the genus Eucalyptus. However, the low rates of embryogenic initiation observed in Eucalyptus (Pinto et al, 2002; Muralidharan and Mascarenhas, 1987), the inability of somatic embryos to reach full maturation (Muralidharan and Mascarenha, 1987) and the occurrence of somaclonal variation (Merkle, 1995; Jain, 2006) may limit the adoption of somatic embryogenesis as a commercial technique forclonal propagation.

Factors such as ontogenetic age of maternal tissue, hormonal levels, type of culture medium used, among others, interfere with the various stages of somatic embryo formation. The presence of high concentrations of auxin, for example, is considered necessary to initially trigger the acquisition of embryogenic competence (Fehér, 2015). Titon et al. (2007) observed structures similar to somatic embryos in juveniles of Eucalyptus grandis after treatment with dicamba and picloram auxins. The composition of the culture medium as well as the ease of assimilation of these compounds with the presence or absence of a gelling agent (Ziv, 1995) may interfere with the development of embryonic structures.

The objective of this work was to study the effects of explant type, auxin concentrations, culture medium and auxin concentrations on the induction and proliferation of somatic embryos of Eucalyptus grandis x E. urophylla.

\section{MATERIALAND METHODS}

\subsection{Plant material}

Two types of explants (seed and cotyledon) were used in the present study, for which hybrid seeds of Eucalyptus grandis $\mathrm{x}$ E. urophylla were obtained from APS 13 of Gerdau, located in Três Marias-MG, in January 2011. For disinfestation, seeds were previously washed in running water and, in a horizontal laminar flow chamber, immersed in $70 \%$ alcohol for $30 \mathrm{sec}$ and then in 5\% sodium hypochlorite for $15 \mathrm{~min}$, with four drops of Tween 20 detergent every $100 \mathrm{~mL}$ of solution. After disinfestation, the seeds were washed six times in autoclaved water. To obtain the cotyledons, the disinfested seeds were placed for germination in sterile disposable Petri dishes $(90 \times 15 \mathrm{~mm})$ containing 30 $\mathrm{mL}$ pre-autoclaved semisolid culture medium at $120^{\circ} \mathrm{C}$ and $1 \mathrm{~atm}$ pressure for $20 \mathrm{~min}$. The culture medium contained $50 \%$ of salts and vitamins MS (MURASHIGE and SKOOG, 1962), 1.5\% sucrose, 50 mg.L $\mathrm{L}^{-1}$ myo-inositol, $2.8 \mathrm{gL}^{-1} \mathrm{Phytagel}^{\circledR}$ and $\mathrm{pH}$ adjusted to $5.8 \pm 0.01$. The seeds were maintained for 7-10 days in a culture room at $24 \pm 1^{\circ} \mathrm{C}$ and a 16-hour photoperiod with irradiance of $33 \mu \mathrm{mol} \mathrm{m}^{-2} \mathrm{~s}^{-1}$ (quantified by a radiometer [LI-COR $\AA$, LI-250A Light Meter] coupled with two tubular fluorescent lamps [Special Daylight, $40 \mathrm{~W}$, Osram, Brazil]).

\subsection{Induction of somatic embryos}

Seeds and cotyledons were used as explants and inoculated in sterile disposable Petri dishes $(60 \times 15 \mathrm{~mm})$ containing $15 \mathrm{~mL}$ MS medium containing $100 \%$ salts and vitamins, 100 mg.L.- ${ }^{-1}$ myo-inositol, $3 \%$ sucrose, Phytagel ${ }^{\circledR} 2.8$ gL $^{-1}$ and $\mathrm{pH}$ adjusted to $5.8 \pm 0.01$, pre-autoclaved at $120^{\circ} \mathrm{C}$ and $1 \mathrm{~atm}$ pressure for $20 \mathrm{~min}$. Subsequently, 1.13, 2.26, 3.39 and $4.52 \mu \mathrm{M} 3$,6-dichloro-o-anisic acid (dicamba) or 4.14, 10.35, 20.71 and $31.06 \mu \mathrm{M} 4$-amino-3,5,6trichloropicolinic acid (picloram) were added; and a control was established without addition of growth regulators. The explants were kept in the culture room, in the dark, at a temperature of $24 \pm 1^{\circ} \mathrm{C}$.

Revista Árvore. 2017;41(5):e410501 
For statistical analysis, two distinct experiments were considered, one with dicamba and the other with picloram. For both, a completely randomized design was used in a $2 \times 5$ factorial scheme, consisting of two types of explants (seeds and cotyledons), five concentrations of growth regulators (dicamba + control, or picloram + control), with six replicates and ten explants/portion.

\subsection{Proliferation of somatic embryos}

Embryogenic calli induced in picloram treatments were used as explants and inoculated into disposable sterile Petri dishes $(60 \times 15 \mathrm{~mm})$ containing $15 \mathrm{~mL}$ semisolid medium or in Erlenmeyer flasks containing $30 \mathrm{~mL} \mathrm{MS} \mathrm{liquid} \mathrm{medium} \mathrm{with} 100 \%$ salts and vitamins, $100 \mathrm{mg} . \mathrm{L}^{-1}$ myo-inositol, 3\% sucrose, $2.8 \mathrm{gL}^{-1}$ Phytagel $^{\circledR}$ (for semisolid medium) and $\mathrm{pH}$ adjusted to $5.8 \pm 0.01$, pre-autoclaved at $120^{\circ} \mathrm{C}$ and $1 \mathrm{~atm}$ pressure for $20 \mathrm{~min}$. $4.14 ; 10.35 ; 20.71$ and $31.06 \mu \mathrm{M}$ picloram, maintaining the origin of the embryogenic calluses (seeds or cotyledons) and the concentration of picloram in which they were in the induction phase.

The explants were kept in the culture room in the dark at a temperature of $24 \pm 1^{\circ} \mathrm{C}$ with shaking at $50 \mathrm{rpm}$ (liquid medium) to maintain oxygenation in the culture medium.

A completely randomized design was used in a $2 \times 4$ factorial scheme (two origins of explants and four concentrations of picloram). Two experiments were considered: the first in semisolid medium containing 4-10 replicates and one embryogenic callus per plot; and the second in liquid medium containing five replicates and two embryogenic calli per plot.

\subsection{Data collection and analyses}

The percentages of somatic pro-embryos (\%SPE), calogenesis (\%CAL) and rhizogenesis (\%RIZ) formed per explant after each treatment of embryo induction experiment were evaluated at 40 days, as well as the number of secondary somatic pro-embryos (SSPE) formed in each explant in semisolid medium for the proliferation experiment.

For all analyses, the statistical program $\mathrm{R}$ (version 3.0.3; R Core Team, 2014) and the ExpDes package (Experimental Designs) (FERREIRA et al. 2013) were used. The variances were compared using the $\mathrm{F}$ test and the means using the Tukey test at 5\% probability.
A descriptive structural analysis was performed in vivo considering color, shape, appearance and origin of SPE or SSPE using a digital camera (Olympus E-330) coupled to a microscope.

For proliferation experiments in liquid medium, only descriptive analyses were performed at days 40 and 80 . While still in the experiment, SSPEs were collected at 80 days, packed in vivo, stained with $0.5 \%$ Evans blue for $3 \mathrm{~min}$ and $0.1 \%$ acetic carmine for another 3 min and photographed using a photomicroscope (AX70TRF; Olympus Optical, Tokyo, Japan) coupled with the U-Photo system.

\subsection{Anatomical characterization}

To obtain the slides for examination by light microscopy, specimens were fixed in glutaraldehyde solution (Karnovsky, (1965) modified: $2.5 \%$ glutaraldehyde, $4 \%$ paraformaldehyde, $3 \%$ sucrose, $\mathrm{CaCl}_{2} 5 \mu \mathrm{M}$ in cacodylate buffer $0.1 \mathrm{M}$ and $\mathrm{pH}$ 6.8) for at least a week, dehydrated in an ethanol series and embedded in methacrylate (Leica Historesin, LeicaBiosystemsNussloch GmbH, Germany). To obtain transverse and longitudinal cuts to $5 \mu \mathrm{m}$ we used an automatic feed rotary microtome (RM 2255, LeicaByosystems) equipped with a glass blade.

The sections were stained with toluidine blue at pH 4.4 (O’brien and Mccully, 1981) for tem minutes, and the slides mounted with synthetic resin (Permount, Fisher Chemical ${ }^{\mathrm{TM}}$, USA). The analysis and photographic documentation were performed under light microscope (Olympus AX-70, Japan), connected to a photomicrography system (Olympus U-Photo, Japan).

\section{RESULTS}

\subsection{Induction of somatic embryos}

Significant differences were found in the interactions between factors (explant type and dicamba concentration) for all characteristics evaluated ( $\% \mathrm{SPE}, \% \mathrm{CAL}$ and $\% \mathrm{RIZ})$. For \%SPE, the use of cotyledon explant provided a higher mean in relation to the seed explant for the concentration of dicamba within $3.4 \mu \mathrm{M}$ (Figure 1A). The ANOVA was conclusive because only two types of explants were compared. For the seed explant, an increasing tendency of $\%$ SPE was observed as the concentration of dicamba increased (Figure 1A). For the cotyledon explant, higher concentrations of $\%$ SPE were reported for $3.4 \mu \mathrm{M}$ followed by $4.5 \mu \mathrm{M}$ (Figure $1 \mathrm{~A}$ ).

Revista Árvore. 2017;41(5):e410502 

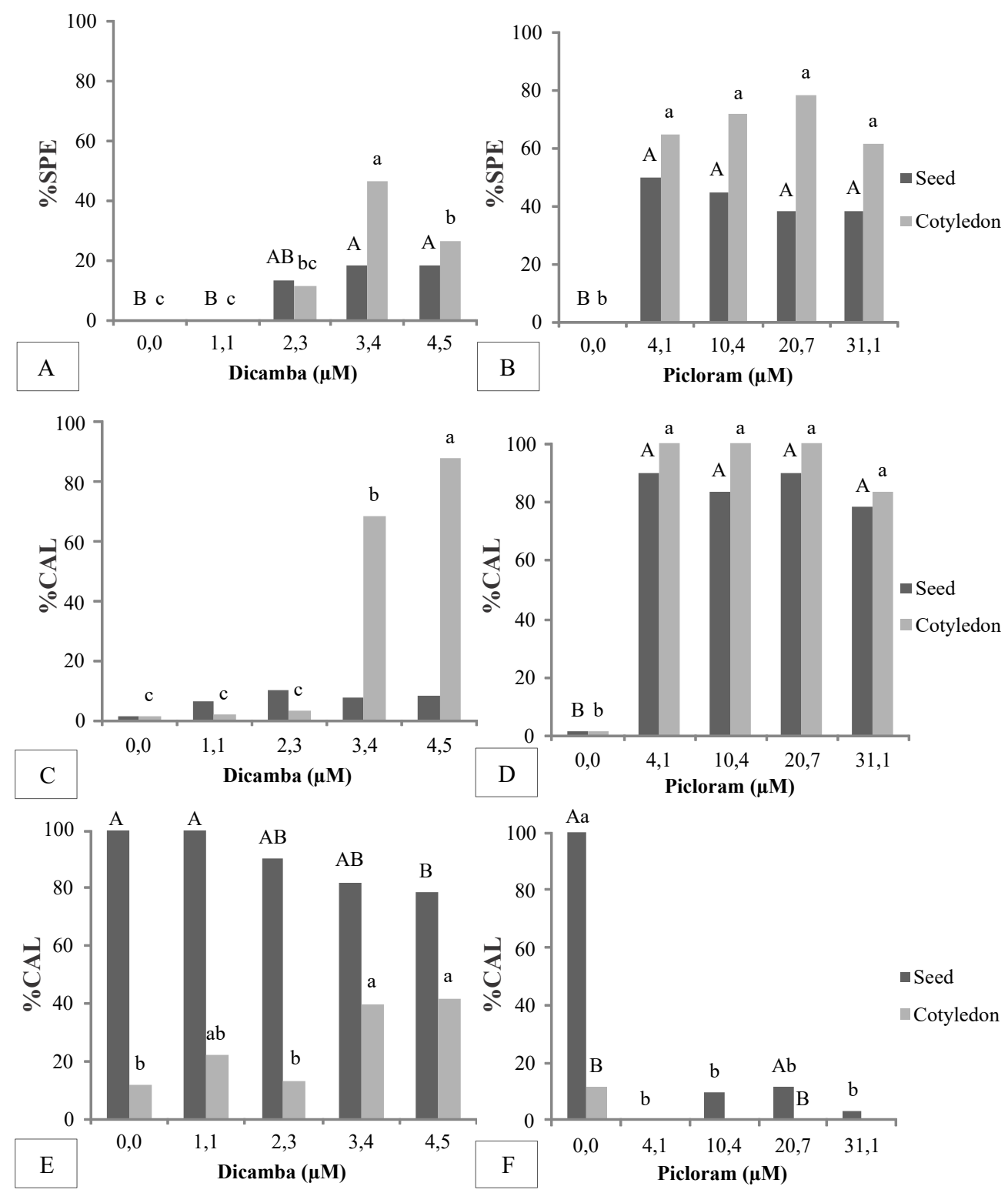

Figure 1 - Percentage of somatic pro-embryos (\%SPE) related to dicamba (A) or picloram (B) concentrations; Percentage of calogenesis $(\% \mathrm{CAL})$ related to dicamba (C) or picloram (D) concentrations; and percentage rhizogenesis (\%RIZ) related to dicamba (E) or picloram (F) concentrations of Eucalyptus grandis $x$ E. urophylla juvenile explants. Bars with the same capital letter between the concentrations of dicamba (A and E) or picloram (B, D and F) within the seed explants between dicamba (A, C and E) or picloram (B D) within the cotyledon explant; and with the same lowercase Greek letter between the explants within some concentrations of dicamba (A, C and E) or picloram (B and $\mathrm{F}$ ) do not differ among themselves by the Tukey test at $5 \%$ probability.

Figura 1 - Porcentagem de pró-embriões somáticos (\% PES) em relação às concentrações de dicamba (A) ou picloram (B); Porcentagem de calogênese (\% CAL) relacionado às concentraçôes de dicamba (C) ou picloram (D); $e$ porcentagem de rizogênese (\% RIZ) relacionado às concentrações de dicamba (E) ou picloram (F) de explantes juvenis de Eucalyptus grandis $x$ E. urophylla.Barras com a mesma letra maiúscula entre as concentrações de dicamba ( $A$ e E) ou picloram ( $B, D$ e $F)$ dentro dos explantes de semente entre dicamba $(A, C$ e $E)$ ou picloram $(B D)$ dentro do explante cotilédone; e com a mesma letra minúscula entre os explantes dentro de algumas concentrações de dicamba ( $A$, C e E) ou picloram (B e F) não diferem entre si pelo teste de Tukey a $5 \%$ de probabilidade.

Revista Árvore. 2017;41(5):e410501 
Based on our results, it can be concluded that the concentrations of dicamba used in the present work were low and did not allow to achieve a maximum induction of somatic pro-embryos, with regard to the seed explant. For the exposed cotyledon, we preferred to repeat the experiment using higher concentrations of this auxin.

For the seed explant, \%CAL remained stable as the concentration of dicamba increased (Figure 1C). For the cotyledon explant, there was an increase in $\%$ CAL following an increase in dicamba concentration, with $4.5 \mu \mathrm{M}$ yielding a higher mean \%CAL (Figure 1C). Within 3.4 and $4.5 \mu \mathrm{M}$, the cotyledon explant was superior over the explant seed in relation to \%CAL (Figure 1C), and since the interaction was significant within these concentrations, the ANOVA was conclusive.

$\%$ RIZ was higher in the seed explant than in the cotyledon explant, in all concentrations of dicamba used (Figure 1E), and the ANOVA was conclusive in the comparison between the two explants. We observed that as the concentration of dicamba increased, \%RIZ decreased in the seed explant, with the highest averages found for the two lowest concentrations. In contrast, for the cotyledon explant, the highest averages were found for the two highest concentrations (Figure 1E).

Significant interactions between the factors (explant type vs. picloram concentration) in terms of all parameters evaluated (\%SPE, \%CAL and \%RIZ) were found. The cotyledon explant was superior over the explant seed within all the picloram concentrations with regard to $\%$ SPE (Figure 1B). The result of the ANOVA was conclusive because it was only two types of explants, with the exception of the control treatment $(0 \mu \mathrm{M}$ picloram), in which the types of explants did not differ among themselves, since there was no occurrence of SPE. For \%CAL, the behavior of the explants within each picloram concentration were similar (Figure 1D). For both the explant seed and the cotyledon explant, all the concentrations of picloram used were higher than the control with regard to \% SPE and \%CAL (Figure 1B and 1D).

For $\%$ RIZ, the effect of auxin picloram was negative for both explants used, with the highest averages occurring in the absence of this growth regulator (Figure 1F). Within the concentrations of 0.0 and $20.71 \mu \mathrm{M}$, the seed explant provided higher mean $\% \mathrm{RIZ}$ in relation to the cotyledon explant, being the result of the ANOVA of the interactions to define the best type of explant.
Among the auxins evaluated, picloram showed more efficient induction of \%SPE and \%CAL for the studied species, presenting $\%$ SPE of $80 \%$, while the highest value found for dicamba did not exceed $50 \%$ (Figure 1A and 1B). In relation to \%RIZ, dicamba provided higher averages when considering both types of explants together.

When whole seeds were used as explants, we observed that they germinated and callus induction or SPE occurred in cotyledonary and root tissues of germinated seedlings (Figure 2A and 2B). An interesting point to note here is that, when picloram was used, the callus and SPE were induced in the aerial part of the explant. In contrast, with the use of dicamba, callus and SPE formation was observed in the explant root portion (Figure 2A and 2B).

In general, the primary somatic embryos appeared bright, yellowish and formed on the adaxial and abaxial faces of the cotyledons. Embryogenic calli appear friable and oxidized (Figure 2C and 2D).

In some somatic pro-embryos, the beginning of differentiation of the protoderm was observed in addition to the initiation of procambium formation. In general, a phenolic cord formation was observed, delimiting the somatic pro-embryo forming cells (Figure 2E-G), which characterizes preforming of somatic embryos in some species.

\subsection{Proliferation of somatic embryos}

In general, SSPEs formed were low, and most of the explants underwent oxidation and died after 40 days of culturing in a semisolid medium. The mean numbers of SSPEs in the explant seed were 0.00, 0.00, 1.00 and 0.80 for $4.14,10.35,20.71$ and $31.06 \mu \mathrm{M}$ picloram, respectively, and for the cotyledon explant were 1.57 , $0.88,1.14$ and 0.80 for $4.14,10.35,20.71$ and $31.06 \mu \mathrm{M}$ picloram, respectively.

We observed that SSPEs and root primers (RPs) were released from the embryogenic callus (EC) and proliferated in all treatments (Figure $3 \mathrm{~A}$ and $3 \mathrm{D}$ ). The SSPE appeared yellowish and shiny and stood out from the initial embryogenic callus (Figure 3B and 3D). These structures, as they are of embryogenic or meristematic origin, were evidenced by the reddish coloration seen after Evans blue and acetic carmine staining (Figure 3C). As in the previous experiment, some SSPEs started the process of protoderm formation and procambio 

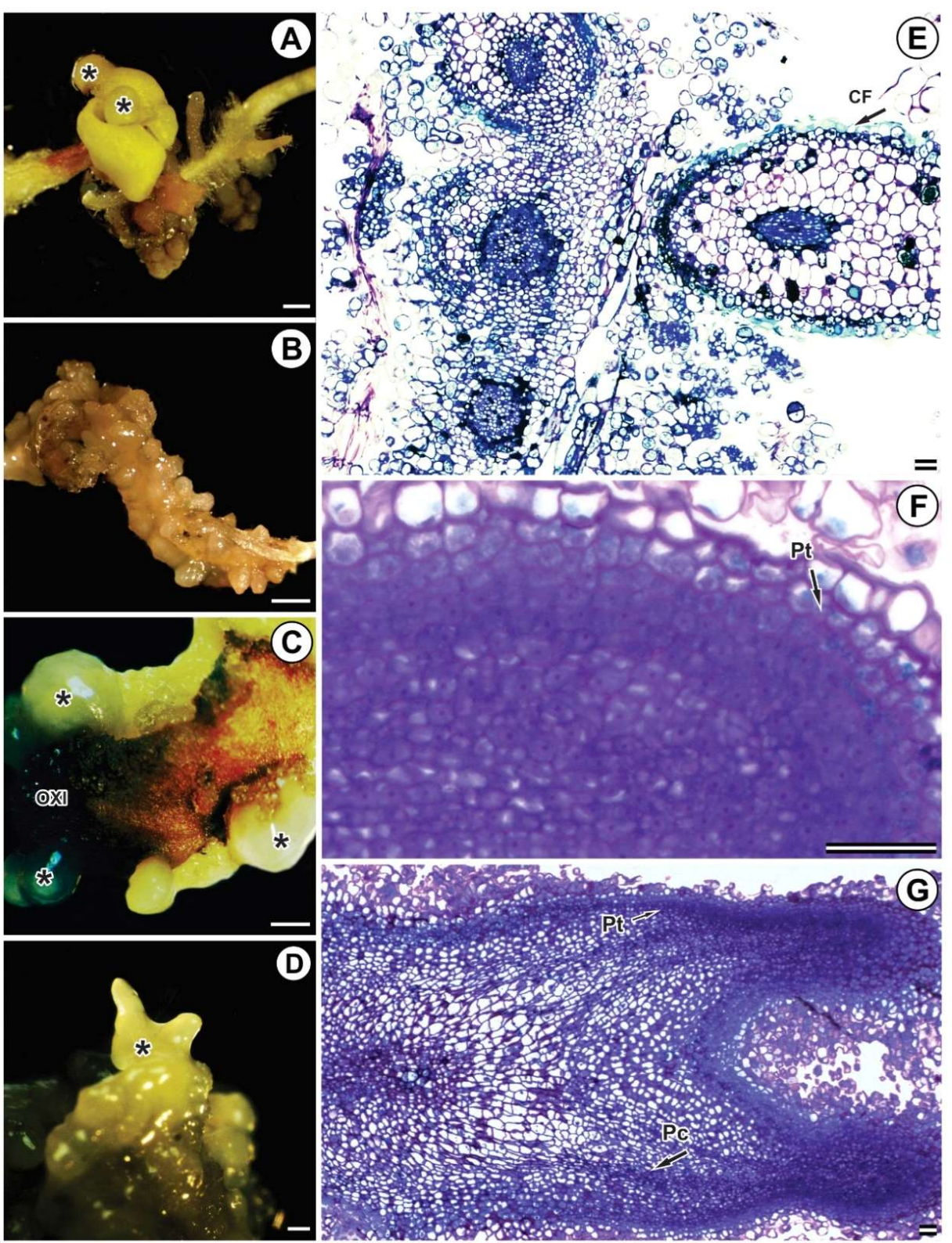

Figure 2 - Somatic pro-embryos (SPE) in Eucalyptus grandis $x$ Eucalyptus urophylla (A, B, C, D) captured by stethoscopy; and longitudinal sections of SPE $(E, F, G)$ obtained by photomicroscopy of light. SPE induced from seeds (A, $\mathrm{B}, \mathrm{D}, \mathrm{E}$, and $\mathrm{G}$ ) or cotyledons ( $\mathrm{C}$ and $\mathrm{F}$ ), in culture media containing dicamba at concentrations of 2.66 iM (A and E), $3.39 \mathrm{iM} \mathrm{(B)} \mathrm{and} \mathrm{picloram} \mathrm{at} \mathrm{concentrations} \mathrm{of} 10.35 \mathrm{iM}(\mathrm{C}, \mathrm{D}, \mathrm{F}, \mathrm{G})$. The bars of figures $\mathrm{A}, \mathrm{B}, \mathrm{C}$ and $\mathrm{D}$ are equivalent to $1 \mathrm{~mm}$, while the bars of other figures are equivalent to $50 \mathrm{im}$. $\mathrm{Pt}=$ Protoderm, $\mathrm{Pc}=$ Procambio and $\mathrm{PC}=$ Phenolic cord, $\mathrm{OXI}=$ oxidation, $*=$ Somatic pro-embryo.

Figura 2 - Pró-embrióes somáticos (PES) em Eucalyptus grandis x Eucalyptus urophylla $(A, B, C, D)$ capturados por estetoscopia; e secções longitudinais de PES $(E, F, G)$ obtidas por fotomicroscopia de luz. PES induzidos a partir de sementes ( $A, B, D, E, e G)$ ou cotilédones $(C$ e $F)$, em meio de cultura contendo dicamba nas concentrações de 2,26 $\mu M(A$ e E) , 3,39 $\mu M(B)$ e picloram na concentração de 10,35 $\mu M(C, D, F, G)$. As barras das figuras $A, B, C$ e D equivalem a $1 \mathrm{~mm}$, a das demais figuras equivalem a $50 \mu \mathrm{m}$. Pt=Protoderme, $P c=P r o c a ̂ m b i o ~ e ~ C F=C o r d a ̃ o$ Fenólico, $O X I=$ oxidação, *=Pró-embrião somático.

Revista Árvore. 2017;41(5):e410501 
(Figure 3E), but some others did not form these structures; or when the protoderm was formed, for some reason, the cells lost their capacity and proliferated again, preventing the completion of training.

\section{DISCUSSION}

In the present study, both whole and cotyledon seeds were found to be efficient sources of explants for the induction of somatic embryogenesis in Eucalyptus urophylla $\mathrm{x}$ E. grandis. The embryogenic potential was higher in embryonic structures (seeds, cotyledons, root apices), probably because these are rich in meristematic tissues, and this potential tends to decrease as the structure matures (leaves, petioles, stems) (Fehér, 2005). Similar to our study, Titon et al. (2007) obtained somatic embryos from Eucalyptus grandis seeds and cotyledons, the second type of explant being the more efficient.

Another important factor in the induction of somatic embryos in Eucalyptus and several other species is the level of auxin present in the cell, which serves as the initial stressing agent for cells that are dedifferentiated (Fehér, 2015). In relation to auxins, picloram was more efficient than dicamba in the induction of somatic embryogenesis under the conditions in which the present work was performed. Titon et al. (2007) also obtained somatic embryos at various stages of development using $20.71 \mu \mathrm{M}$ picloram in Eucalyptus grandis explants.

At the cellular level, auxins regulate cell division, expansion, and differentiation. Depending on the specific tissue, auxins may promote axial elongation, lateral expansion, or isodiametric expansion (Taiz and Zeiger, 2013). In addition, synthetic auxins act indirectly by disrupting endogenous auxin metabolism, promoting cellular reorganization and inducing somatic embryogenesis (Fehér et al. 2003). Thus, the type and concentration of exogenous auxin required to induce somatic embryogenesis are highly variable among species. Picloram has been shown to be effective in inducing somatic embryogenesis in species such as barley (Sener et al. 2008), tulip (Ptak and Bach, 2007), pupunha (Steinmacher et al. 2007), macaw palm (Moura et al. 2009), and palm (Scherwinski-Pereira et al. 2010).

For the proliferation experiment, the liquid medium showed much promise as compared to the semisolid medium regarding the induction of secondary embryogenesis. The results of the present study were similar to those reported in literature (Levin et al. 1997; Chen and Ziv, 2001), which reported no physical resistance to diffusion of these components when compared to a culture medium of semi-solid consistency. Moreover, the greater contact of explants with the medium giving rise to a higher rate of assimilation of compounds by the plant material favors the liquid medium (Ziv, 1995).

Despite the incomplete formation of somatic embryos in the present study, observations such as reddish staining of the structures, early protoderm formation, presence of phenolic cord surrounding the embryonic structures, and the disconnection between primary and secondary structures suggest the preformation of primary and secondary somatic embryos. Previously, such events were evidenced during somatic embryogenesis in species such as macaw palm, where the presence of phenolic compounds, intense cell division, and the progeny strands undergoing intense multiplication and tissue differentiation were reported (Moura et al. 2009). Thus, new experiments of longer duration are necessary to prove the results of the present study.

It is worth noting that the proliferation of secondary embryos from preformed primary embryos may have led to the malformation of new embryos, leading to oxidation and death. In this situation, the deviation of as-yet-undifferentiated cells that were still expressing totipotency may have occurred.

Despite the initial induction of somatic embryos and the proliferation of secondary somatic embryos, these structures did not develop for germination and seedling formation (unpublished data). Obviously, the initiation of embryogenic development in a differentiated cell requires complete cellular reprogramming (Fehér, 2005). The recalcitrance or competence to somatic embryogenesis also depends on the genetic factor, as previously shown for Eucalyptus by Pinto et al. (2008).

It is widely accepted that a precise control of chromatin modifications in response to environmental and developmental stimuli determines the correct spatial and temporal expression of genes (Fehér, 2015). Although auxin is required, this is insufficient to create the initiation of embryogenesis in somatic plant cells on its own (Fehér, 2015). A plausible model of induction of somatic embryogenesis can, therefore, be based on (at least) two factors: auxin, which is responsible for an appropriate 


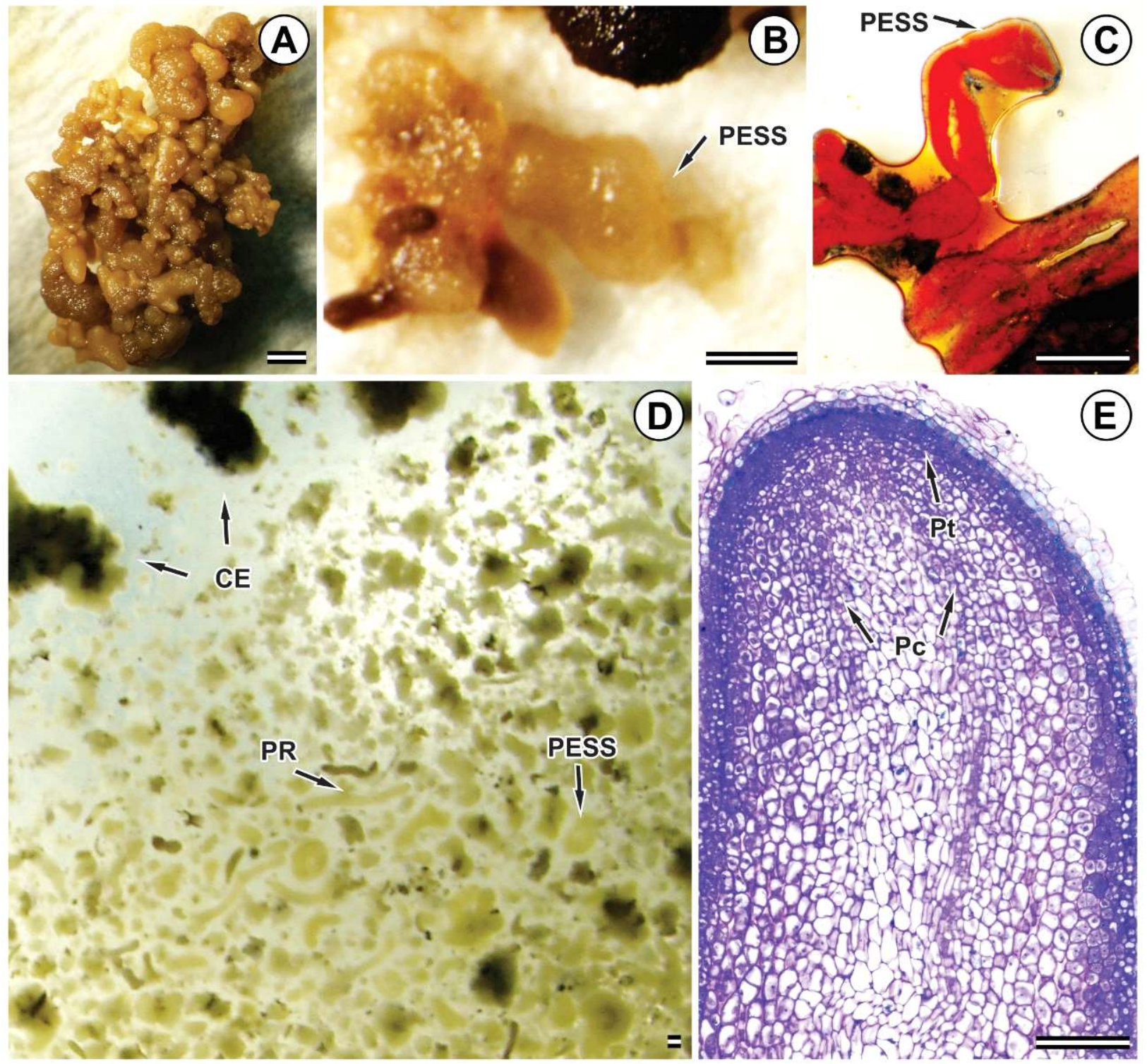

Figure 3 - Secondary somatic pro-embryos (SSPE) in Eucalyptus grandis $x$ Eucalyptus urophylla (A, B and D) captured by stethoscopy (C) and longitudinal section of SSPE (E) obtained by photomicroscopy of light. SSPE induced from embryogenic callus (EC), in culture medium containing picloram at concentrations of $4.14 \mathrm{iM}$ (A) and 20.71 $\mathrm{iM}(\mathrm{B}, \mathrm{C}, \mathrm{D}$ and E). Figure D corresponds to the liquid proliferation medium containing SSPE, EC and radicular primers (RPs). The bars of Figure $\mathrm{E}$ are equivalent to $100 \mathrm{iM}$ and those of other figures are equivalent to $1 \mathrm{~mm}$. $\mathrm{Pt}=$ Protoderm; $\mathrm{Pc}=$ Procambio.

Figura 3 - Pró-embriões somáticos secundários (PESS) em Eucalyptus grandis x Eucalyptus urophylla (A, B e D) capturados por estetoscopia; estrutura compactada in vivo (C) e secção longitudinal de PESS (E) obtidas por fotomicroscopia de luz. PESS induzidos a partir de calos embriogênicos (CE), em meio de cultura contendo picloram nas concentrações 4,14 $\mu M(A)$ e 20,71 $\mu M(B, C c, D$ e E). A figura D corresponde ao meio de proliferação líquido contendo PESS, $C E$ e primórdios radiculares (PR). A barra da figura E equivale a $100 \mu \mathrm{M}$ e as demais barras das demais figuras equivalem a $1 \mathrm{~mm}$. Pt= Protoderme; $P c=$ Procâmbio.

Revista Árvore. 2017;41(5):e410501 
cell environment factor, and an unknown factor(s), including stress and genetic factor, that triggers the embryogenic program (FEHÉR, 2005). Thus, molecular studies would be interesting to elucidate which genes and factors are linked throughout the embryogenic process, as well as the evaluation of other components of the culture medium, such as $\mathrm{pH}$, calcium or vitamin concentrations, and types of growth regulators with regard to Eucalyptus.

\section{CONCLUSIONS}

Here, the induction of somatic pro-embryos in juvenile plant material of Eucalyptus grandis $\mathrm{x} E$. urophylla was studied using seeds or cotyledons as a source of explants, and dicamba and picloram as growth regulators. The use of cotyledons as a source of explants and picloram at a concentration of $4.1 \mu \mathrm{M}$ promoted higher averages in the induction of somatic pro-embryos. We propose that the proliferation of secondary somatic pro-embryos can be achieved using a liquid medium supplemented with picloram.

\section{REFERENCES}

Chen J, Ziv M.The effect of ancymidol on hyperhydricity, regeneration, starch and antioxidant enzymatic activities in liquid-culture Narcissus. Plant Cell Reports. 2991.20:22-7.

Fehér A. Somatic embryogenesis - stress induced remodeling of plant cell fate.Biochimica et Biophysica Acta. - Gene Regulatory Mechanisms. 2015;1849(4):385-402.

Fehér A. Why somatic plant cells start to form embryos? Plant Cell Monographs. 2005;2:85-101.

Fehér A, Pasternak TP, Dudits D. Transition of somatic plant cells to an embryogenic state. Plant Cell, Tissue and Organ Culture. 2003;74:201-28.

Ferreira EB, Cavalcanti PP, Nogueira DA. ExpDes: Experimental designs pacakge. R package version 1.1.2.2013. 42p.

Jain SM. An update on overall recent progress on somatic embryogenesis in forest trees. In: Suzuki K, Ishii K, Sakurai S, Sasaki S editors. Plantation technology in tropical forest science. Tokyo: Springer; 2006. p.113-22.
Karnovsky MJ. A formaldehyde-glutaraldehyde fixative of high osmolality for use in electron microscopy. Journal of Cell Biology. 1965;27:137-8.

Levin R, Alper Y, Stav R, Watad A. Methods and apparatus for liquid media and semi-automated micropropagation. Acta Horticulturae. 1997;447:659-63.

Merkle SA. Strategies for dealing with limitations of somatic embryogenesis in hardwood trees. Plant Tissue Culture Biotechnology.1995;1:112-21.

Moura EF, Motoike SY, Ventrella MC, Sá Júnior AQ, Carvalho M. Somatic embryogenesis in macaw palm (Acrocomia aculeata) from zygotic embryos. Scientia Horticulturae. 2009;119:447-54.

Murashige T, Skoog F. A revised medium for rapid growth and bioassays with tobacco tissue cultures. Physiologia Plantarum. 1962:15:473-97.

Muralidharan EM, Gupta PK, Mascarenhas AF. Plantlet production through high frequency somatic embryogenesis in long term cultures of Eucalyptus citriodora. Plant Cell Reports. 1989;8:41-3.

Muralidharan EM, Mascarenhas AF. In vitro plantlet formation by organogenesis in E. camaldulensis and by somatic embryogenesis in Eucalyptus citriodora. Plant Cell Reports. 1987;6:256-9.

O'Brien TP, Mccully ME. The study of plant structure principles and selected methods. Melbourne: Termarcarphi Pty; 1981.357p.

Ptak A, Bach A. Somatic embryogenesis in tulip (Tulipa gesneriana L.) flower stem cultures. In Vitro Celular and Developmental Biology - Plant. 2007;43:35-9.

Pinto G, Santos C, Neves L, Araújo C. Somatic embryogenesis and plant regeneration in Eucalyptus globulus Labill. Plant Cell Reports. 2002;21:208-13.

Pinto G, Park EYS, Neves EL, Araújo EC, Santos EC. Genetic control of somatic embryogenesis induction in Eucalyptus globules Labill. Plant Cell Reports. 2008;27:1093-101. 
R Core Team. R: A language and environment for statistical computing. Vienna: R Foundation for Statistical Computing; 2014. Disponível em: http:// www.Rproject.org/.

Rai MK, Shekhawat NS. Recent advances in genetic engineering for improvement of fruit crops. Plant Cell, Tissue and Organ Culture. 2014;116:1-15.

Scherwinski-Pereira J, Guedes RS, Fermino PC, Dilva TL, Costa FH. Somatic embryogenesis and plant regeneration in oil palm using the thin cell layer technique. In Vitro Celular and

Developmental Biology - Plant. 2010;46:378-85.

Sener O, Can E, Asrlan M, Celis N. Effects of genotype and picloram concentrations on callus induction and plant regeneration from immature inflorescence of spring barley cultivars (Hordeum vulgare L.). Biotechnoly and Biotechnolical Equipament. 2008;22:915-20.
Steinmacher DA, Cangahuala-Inocente GC, Clement CR, Guerra MP. Somatic embryogenesis from peach palm zygotic embryos. In Vitro Celular and Developmental Biology - Plant. 2007;43:124-32.

Taiz L, Zeiger E. Fisiologia vegetal. $5^{\mathrm{a}}$ ed. Porto Alegre: Artmed; 2013.918p.

Titon M, Xavier A, Otoni WC, Motoike SY. Efeito dos reguladores de crescimento dicamba e picloram na embriogenese somática em Eucalyptus grandis. Revista Árvore. 2007;31(3):417-26.

Ziv M. The control of bioreactor environment for plant propagation in liquid culture. Acta Horticulturae. 1995;393:25-38.

Us-Camas R, Rivera-Solís G, Duarte-Aaké F, DeLa-Pêna C. In vitro culture: na epigenetic challenge for plants. Plant Cell, Tissue and Organ Culture. 2024;118:187-201. 